\title{
ПОДХОДЫ РЕСПУБЛИКИ БЕЛАРУСЬ К ИНСТИТУЦИОНАЛЬНОЙ РЕФОРМЕ ГЕНЕРАЛЬНОЙ АССАМБЛЕИ ООН В 2005-2020 ГГ.
}

\author{
Д.В. ЛУЗАН, С.Ф. СВИЛАС \\ Белорусский государственный университет \\ Минск, Республика Беларусь
}

Уже более 20 лет мировое сообщество находится в активном поиске решения проблемы реформирования Организации Объединенных Наций, однако консенсус так и не достигнут. В этой связи детальный анализ позиций отдельных государств является значительным шагом на пути к достижению согласия, позволяя найти точки соприкосновения в проектах реформы.

В статье на основе анализа текстов выступлений белорусских дипломатов с трибуны ООН и посредством междисциплинарной методологии определены цели, принципы, направления участия белорусской дипломатии в процессе модернизации ООН, содержатся характеристика и комплексная оценка подходов Республики Беларусь к институциональной реформе Генеральной Ассамблеи. Выделены три пика внешнеполитической активности республики в указанной области, раскрыто их содержание. Особое внимание уделено таким направлениям, как эффективность дискуссий, правовое сопровождение модернизации, система финансирования, повестка дня ГА. Подчеркнута важность расширения практики проведения тематических дебатов по ключевым проблемам современности, повышения эффективности взаимодействия Генеральной Ассамблеи с Советом Безопасности, развития сотрудничества с гражданским обществом.

Белорусская дипломатия исходит из необходимости укрепления роли ГА как главного представительного и совещательного органа ООН, усиления позиции Ассамблеи, ее Председателя и его Канцелярии при избрании Генерального секретаря, но без ущемления полномочий Совета Безопасности. Обоснован вывод о том, что в отношении институциональной реформы Генеральной Ассамблеи Беларусь занимает «центристскую» позицию. Предложения белорусской дипломатии направлены главным образом на корректировку работы этого органа без изменения его места и роли в системе Организации. Исследование призвано восполнить существующий в научной и публицистической литературе пробел в изучении проблематики реформирования Генеральной Ассамблеи с позиции Республики Беларусь. 
Ключевые слова: внешняя политика и дипломатия Республики Беларусь; постбиполярная система международных отношений; глобализация; международное сотрудничество; многосторонняя дипломатия; реформирование $\mathrm{OOH}$; Генеральная Ассамблея $\mathrm{OOH}$; антропология международных отношений.

Образец цитирования: Лузан Д. В., Свилас С. Ф. Подходы Республики Беларусь к институциональной реформе Генеральной Ассамблеи ООН в 2005-2020 гг. // Актуальные проблемы международных отношений и глобального развития : сб. науч. ст. Минск, 2020. Вып. 8. С. 58-74. https://doi.org/10.33581/23119470-2020-8-58-74

Введение. Завершение 75 лет назад Второй мировой войны ознаменовалось созданием Организации Объединенных Наций международного форума коллективной безопасности и стабильности на планете. С тех пор мир перетерпел значительные изменения: на политической карте появилось более ста новых суверенных государств, сформировалась и прекратила свое существование биполярная система международных отношений, возросла роль международных организаций как активных акторов международных отношений.

Качественные и количественные изменения произошли и в самой ООН. Число государств - членов с 1945 г. возросло почти в 4 раза, был образован новый постоянно функционирующий орган - Совет по правам человека (2006 г.), в то время как один из центральных органов - Совет по опеке - приостановил свою работу (с 1994 г.). Однако Генеральная Ассамблея ООН продолжает рассматривать мир как всеобщую «конфедерацию», играть роль глобального парламента, а отношение числа членов Совет Безопасности к общему количеству государств-членов Организации достигло критического минимума менее 8\% (в 1945 г. - около 22\%). Подобные тенденции отнюдь не способствуют повышению эффективности деятельности ООН на международной арене, а зачастую являются факторами снижения кредита доверия государств к Организации.

Вместе с тем необходимость в сильной и авторитетной Организации Объединенных Наций только возросла. В начале XXI века многие государства, поддерживая тенденцию к полицентризму в условиях гегемонии США, выразили озабоченность снижением роли ООН в международных отношениях, поставили вопрос о комплексном реформировании Организации с целью укрепления ее авторитета и влияния в мировом сообществе. Не осталась в стороне и Республика Беларусь, которая принимает активное участие в обсуждении рефор- 
менных проектов Организации. Особое место в белорусских проектах реформы занимает Генеральная Ассамблея.

Цель исследования состоит в характеристике и оценке позиции Республики Беларусь по реформированию Генеральной Ассамблеи ООН в 2005-2020 гг.

В рамках исследования были поставлены следующие задачи: определить основные цели, принципы и направления белорусской дипломатии в процессе реформирования Организации Объединенных Наций; рассмотреть подходы Республики Беларусь к реформированию ГА ООН; проанализировать и охарактеризовать позицию республики по вопросу об активизации Генеральной Ассамблеи.

Хронологические рамки исследования - 2005-2020 гг. Период между 60-ым и 75-ым юбилеями Организации Объединенных Наций характеризуется резким повышением внимания к проблеме реформирования ООН в целях адаптации и актуализации ее работы в условиях глобальных вызовов, активизацией практических разработок государств-членов, в том числе в направлении реформы Генеральной Ассамблеи, формированием конкретных ориентиров и приоритетов модернизации институтов Организации и ООН в целом. В рамках данного периода можно выделить три пика активности белорусской дипломатии в направлении реформы Генассамблеи.

Первый пик приходится на 2004-2006 гг., совпадает с 60-летием Организации и сопутствующими этому событию мероприятиями. Состоявшаяся 2 декабря 2004 г. презентация доклада Группы высокого уровня «Безопасный мир: наша общая ответственность», а также представление 21 марта 2005 г. доклада Генерального секретаря ООН Кофи Аннана «При большей свободе» стали мощным толчком для всех государств - членов на пути к активным разработкам собственных проектов реформы. В этот период сформировались основные принципы Республики Беларусь в отношении реформирования $\mathrm{OOH}$ вообще и Генеральной Ассамблеи в частности, которые в дальнейшем развивались.

Второй пик активизации практических разработок Беларуси в векторе реформирования Генассамблеи приходится на 2010-2013 гг. Он характеризовался проведением всестороннего анализа результатов, достигнутого за пять лет со времени реализации «первой партии» реформ (2006 г.) и формированием на этой основе новых ориентиров и целей. Как и другие государства, Беларусь в это время была вовле- 
чена в процесс выработки оригинальных положений и проектов реформы ГА и корректировала уже разработанные позиции.

После избрания на должность Генерального секретаря Антониу Гутерриша (2017 г.) в Организации Объединенных Наций вновь всерьез заговорили о необходимости проведения реформ. Именно этими событиями обусловлен третий пик в процессе формирования взглядов белорусской дипломатии на различные нюансы и аспекты реформенных процессов в Генеральной Ассамблее.

Актуальность исследования определяется значимостью ООН в современных международных отношениях и во внешней политике Республики Беларусь, а также недостаточной разработанностью вопроса в историографии.

Научная новизна исследования состоит в том, что впервые в науке о международных отношениях были проведены анализ, синтез и оценка подходов Республики Беларусь к реформированию Генеральной Ассамблеи ООН; в научный оборот введены актуальные данные, позволяющие раскрыть суть подходов республики к решению основных проблем этого центрального института Организации.

Методы исследования. Исследование основано на принųипах объективности, историзма, системности и ценности в истории. В рамках исследования был применен комплекс общенаучных (анализ, синтез, сравнение, обобщение, индукция, дедукция) и специальных методов (историко-сравнительный, историко-системный, анализа документов, включенного наблюдения, институциональный, структурно-функциональный, системного анализа), а также ценностный, антропологический, макро- и микросоциологический noдxoдbl.

Объектом исследования является внешняя политика и дипломатия Республики Беларусь.

Предмет исследования - инициативы, предложения и проекты белорусской дипломатии по реформированию Генеральной Ассамблеи ООН, внесенные официальным Минском в 2005-2020 гг.

Обзор историографии по теме. Различные аспекты реформирования Организации Объединенных Наций представлены в историографии достаточно широко. В российской историографии крупными экспертами по этой проблеме являются Л. Е. Гришаева ${ }^{1}$,

\footnotetext{
${ }^{1}$ Гришаева Л. Е. ООН: формально существующая или реально действующая // Дипломатическая служба. 2018. №1. С. 19-30.
} 
А. И. Никитин ${ }^{2}$, В. Котляр ${ }^{3}$; диссертация на соискание ученой степени доктора наук защищена В. Ф. Заемским [1], кандидатские диссертации - М. М. Юрченко [2], Е. В. Головановым [3] и Р. Ю. Пламаренко [4]. В западной историографии следует выделить работы Т. Вейса ${ }^{4}$, Э. Лака ${ }^{5}$, И. Мюллера ${ }^{6}$ и особенно - М. Гулдинга ${ }^{7}$.

Подходы же белорусской дипломатии к реформированию Организации Объединенных Наций в историографии освещены недостаточно. Данной проблематики касался кадровый дипломат А. Н. Сычев в статье «Республика Беларусь и ООН» (2006 г.) [5], который рассмотрел подходы Республики Беларусь к реформированию Организации и выделил в качестве приоритетных направлений адаптацию состава Совета Безопасности к современным реалиям, активизацию Генеральной Ассамблеи и работу над уточнением положений Устава ООН.

Тема реформирования ООН затрагивалась А. В. Тихомировым в монографии «Внешняя политика Республики Беларусь (19912015 гг.)» (2017 г.) [6], а также в статье «Взаимодействие Республики Беларусь и ООН (1991-2015 гг.)» (2015 г.) [7]. Он высказал мнение, что в начале XXI века Беларусь делала ставку на рационализацию деятельности центральных органов ООН путем наделения их «адекват-

Гришаева Л. Е. ООН: 75 лет после Второй мировой войны // Дипломатическая служба. 2020. №5. С. 6-32.

${ }^{2}$ Никитин А. И. Новая система отношений великих держав XXI века: «концерт» или конфронтация? // Полис. 2016. № 1. С. 44-59.

Никитин А. И. Миротворчество ООН: обновление принципов, реформирование практики // Мировая экономика и международные отношения. 2016. № 3. С. 16-26.

${ }^{3}$ Котляр B. Реформа ООН и вопрос о возрождении Военно-Штабного Комитета при Совете Безопасности ООН // Международное публичное и частное право. 2006. №6. С. 64-72.

${ }^{4}$ Weiss T. G., Young K. E. (2005) Compromise and Credibility: Security Council Reform? In: Security Dialogue, Vol. 36, p. 146-168.

Thomas G. Weiss, Sir Brian Urquhart. (2013) What's Wrong with the United Nations and How to Fix it. Wiley, 288 p.

${ }^{5}$ Luck E. C. (2006) The Survivors: The United States and the United Nations in Troubled Times. In: American Foreign Policy Interests, Vol. 28, p. 293-296.

Edward C. Luck. (2003) Reforming the United Nations: Lessons from a History in Progress. In: New Haven: Academic Council on the UN System, 74 p.

${ }^{6}$ Joachim Mueller. (2016) Reforming the United Nations: A Chronology. BRILL, 440 p.

Joachim Müller. (2010) Reforming the United Nations: The Challenge of Working Together. Martinus Nijhoff Publishers, 386 p.

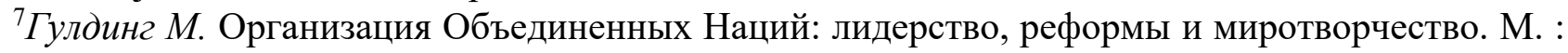
Московский центр Карнеги. 2007. 
ными возможностями для эффективной реализации уставных целей и задач».

В коллективной монографии «Внешняя политика Республики Беларусь в 2000-е гг.» (2010 г.) [8], изданной под редакцией профессора А. В. Шарапо, акцент делается на реформе Совета Безопасности: подчеркнуто стремление Беларуси сделать этот орган более представительным, а также расширить присутствие группы восточноевропейских государств в категории его непостоянных членов.

Вместе с тем многоаспектная и развернутая оценка подходов Республики Беларусь к реформированию такого центрального института ООН, как Генеральная Ассамблея, в научной и публицистической литературе отсутствует.

Результаты исследования. В результате исследования выявлено, что в рамках максимизации эффективности реформенных процессов всех структур ООН белорусская сторона считает необходимым сосредоточиться на реализации следующих общих задач: участие в реализации согласованных мер всех без исключения государств членов; мобилизация всех доступных политических, экономических, интеллектуальных и иных ресурсов; воплощение в жизнь в полной мере Организацией, которая является универсальной и по составу, и по своему мандату, роли лидера в объединении и координации международных усилий ${ }^{8}$ Развивая последний тезис, белорусская дипломатия делает акцент на том, что в свете появления новых субъектов в сфере мировой политики (узкие клубы, неформальные объединения, союзы и др.) их встраивание в систему ООН, в особенности рациональное включение в работу Генеральной Ассамблеи, является основой понятной, согласованной и эффективной работы Организации 9 .

В основе подходов Республики Беларусь к институциональной реформе ООН, включающей также и реформу Генеральной Ассамблеи, лежат три базовых принципа. Глава республиканского внешнеполитического ведомства В. Макей, выступая на 72-ой сессии Генеральной Ассамблеи, отмечал: «Во-первых, реформа должна быть про-

\footnotetext{
${ }^{8}$ Выступление Министра иностранных дел Беларуси В. Макея в общей дискуссии на 74-й сессии Генеральной Ассамблеи ООН // Министерство иностранных дел Республики Беларусь. 2019. URL : http://mfa.gov.by/press/statements/f13cbe96fb645ac8.html (дата обращения: 22.04.2020).

${ }^{9}$ Выступление Министра иностранных дел Республики Беларусь В. В. Макея на 72-ой сессии Генеральной Ассамблеи ООН // Министерство иностранных дел Республики Беларусь. 2017. URL : http://mfa.gov.by/upload/Statement_UN_GA.pdf (дата обращения: 22.04.2020).
} 
зрачной, логичной и ориентированной на результаты. Во-вторых, реформа не должна привести к бюрократизации и увеличению нагрузки на государства - члены. В-третьих, реформа должна быть инклюзивной - голос каждого государства-члена должен быть услышан» ${ }^{10}$.

В течение последних лет Беларусь также фокусируется на вопросах внутреннего микроклимата Организации и ее структур. По оценке В. Макея, «в ООН не видно общего стремления со стороны всех государств найти решение вопроса. Многие государства зацикливаются только лишь на каких-то взаимных обвинениях в адрес друг друга ${ }^{11}$.

В этой связи белорусская сторона призывает членов ООН вернуться к конструктивному диалогу и стремиться к всеобщему согласию и консенсусу (в том числе в рамках дискуссий о реформе), чтобы Организация «оставалась реальной площадкой, где государства совместно с международными чиновниками могут найти решение глобальным проблемам» ${ }^{12}$. По убеждению белорусской дипломатии, такой диалог должен оставаться приоритетным форматом работы Генассамблеи.

Важным аспектом процесса модернизации Генеральной Ассамблеи является его правовое сопровождение. Выступая против ревизии положений Устава, фиксирующих фундаментальные принципы работы ООН и, в частности, Генассамблеи ${ }^{13}$, Беларусь считает, что вопрос о взаимодействии последней с Советом Безопасности недостаточно урегулирован. В этой связи Специальный комитет по Уставу ООН и усилению роли Организации рассматривается Минском в качестве основного форума для обсуждения и решения вопросов, связанных с

\footnotetext{
10 Там же.

11 Беларусь: ООН - по-прежнему «ядро» международной жизни, интервью В. Макея // Новости ООН. 2018. URL : https://news.un.org/ru/story/2018/10/1339832 (дата обращения: 29.03.2020).

12 Выступление представителя делегации Республики Беларусь А. Ржеусского по п.125 «Укрепление ООН», п.126 «Реформа ООН: меры и предложения» на 73-ей сессии Генеральной Ассамблеи ООН // Портал «United Nations PaperSmart». 2018. URL https://papersmart.unmeetings.org/media2/19409584/belarus.pdf (дата обращения: 26.04.2020).

13 Выступление заместителя Министра иностранных дел Республики Беларусь А. Н. Сычёва на пленарном заседании Генеральной Ассамблеи ООН по пунктам повестки дня «Активизация работы Генеральной Ассамблеи ООН» и «Укрепление системы ООН» // Министерство иностранных дел Республики Беларусь. 2004.2 URL http://mfa.gov.by/press/statements/e023254741b065c3.html (дата обращения: 29.03.2020).
} 
правовыми аспектами реформирования и повышения эффективности деятельности Генеральной Ассамблеи ${ }^{14}$.

Кроме того, Беларусь, поддерживая принцип многосторонности в международных отношениях, всерьез обеспокоена неблагоприятными тенденциями, наметившимися в системе финансирования ООН. Республика отмечает возможные негативные последствия в части беспристрастности при реализации финансирования отдельных направлений работы Организации и Генассамблеи, в частности, исключительно за счет внебюджетных средств. Как отмечал В. Рыбаков, выражая позицию белорусской стороны по данному вопросу, «финансирование ООН должно осуществляться из регулярного бюджета ООН за счет взносов государств - членов ООН, а не зависеть от спонсорской помощи» ${ }^{15}$.

В поисках решения вопроса о реформе Генеральной Ассамблеи $\mathrm{OOH}$ Республика Беларусь прежде всего исходит из необходимости активизации работы этой структуры ${ }^{16}$ посредством урегулирования проблемы перегруженности повестки дня [5], а также сбалансированного распределения основных пунктов между главными комитетами $\Gamma^{17}$. В этой связи Республика Беларусь активно продвигает идею двухгодичного (а при необходимости трехгодичного ${ }^{18}$ ) цикла рассмотрения повестки дня Генассамблеей. По мнению В. Рыбакова, «такой шаг не пошлет никакого негативного сигнала о том, что какието вопросы важнее и приоритетнее других, но при этом кардинально

\footnotetext{
${ }^{14}$ Выступление заместителя начальника главного договорно-правового управления МИД Беларуси Людмилы Татаринович в рамках обсуждения Доклада Специального комитета по Уставу ООН и усилению роли Организации // Министерство иностранных дел Республики Беларусь. 2013. URL : http://www.mfa.gov.by/press/statements/ba6821a80eb36a98.html (дата обращения: 19.04.2020).

15 Выступление Валентина Рыбакова, Постоянного представителя Республики Беларусь при ООН по п.121 «Активизация работы Генеральной Ассамблеи» на 73-ей сессии Генеральной Ассамблеи ООН // Портал «United Nations PaperSmart». 2018. URL : https://papersmart.unmeetings.org/media2/20305683/belarus.pdf (дата обращения: 26.04.2020).

16 Беларусь и реформа ОOH // Министерство иностранных дел Республики Беларусь. URL : http://mfa.gov.by/mulateral/organization/list/un/db41d8fbd2106c7f.html (дата обращения: 29.03.2020).

17 Выступление заместителя начальника главного управления многосторонней дипломатии начальника управления экономического сотрудничества и устойчивого развития МИД Беларуси Юрия Ярошевича на пленарном заседании 67-й сессии Генеральной Ассамблеи ООН, посвященном активизации работы этого органа // Министерство иностранных дел Республики Беларусь. 2012. URL : http://mfa.gov.by/press/statements/e24157df613721db.html (дата обращения: 19.04.2020).
}

${ }^{18}$ CM. 15. 
поменяет формат нашей [Генеральной Ассамблеи] работы и даст делегациям больше возможностей работать над всеми пунктами повестки дня, что, в конечном итоге, приведет к повышению качества принимаемых документов» ${ }^{19}$.

Белорусская сторона критикует практически полное дублирование пунктов повесток оперативного сегмента Экономического и Социального Совета (ЭКОСОС) и Второго комитета ГА, а также гуманитарного сегмента ЭКОСОС и Третьего комитета ГА ${ }^{20,21}$. Отметим, что она до определенного времени придерживалась другой позиции и воздерживалась от критики по этому вопросу 22 .

Дублирование приводит к копированию положений принятых резолюций в новых по аналогичной теме. Как обоснованно заявил В. Рыбаков, «встает совершенно резонный вопрос: зачем?» В этой связи белорусская дипломатия приветствовала усилия Специальной рабочей группы по активизации Генеральной Ассамблеи на 73-ей сессии, предпринявшей значительные меры по разгрузке повестки дня, и намерена поддерживать усилия в данном направлении ${ }^{23}$.

В рамках оптимизации рассмотрения пунктов повестки дня ГА Беларусь призывает к более рациональной дискуссии по пунктам «Общие прения» и «Доклад Генерального секретаря ООН о работе Организации». Белорусская дипломатия апеллирует к тому, что доклад Генерального секретаря презентуется в рамках общих прений, посвященных ежегодно определяемой председателем ГА проблеме, и не соотносится с обозначенной темой. В противовес устоявшейся традиции, предложение Беларуси заключается в необходимости

\footnotetext{
19 Официальный отчет 29-ого пленарного заседания 74-ой сессии Генеральной Ассамблеи ООН, выступление г-на Рыбакова // Цифровая библиотека Организации Объединенных Наций. 2019. URL : https://digitallibrary.un.org/record/3841580? $1 \mathrm{n}=\mathrm{ru}$ (дата обращения: 26.04.2020).

${ }^{20}$ Официальный отчет 14-ого пленарного заседания 74-ой сессии Генеральной Ассамблеи ООН, выступление г-на Дапкюнаса // Цифровая библиотека Организации Объединенных Наций. 2019. URL : https://digitallibrary.un.org/record/3838078? $1 \mathrm{n}=\mathrm{ru}$ (дата обращения: 26.04.2020).

${ }^{21}$ См. 19.

22 Выступление заместителя Постоянного представителя Республики Беларусь при ООН Сергея Рачкова по пункту 42 повестки дня «Доклад Экономического и Социального Совета на 61-ой сессии Генеральной Ассамблеи // Министерство иностранных дел Республики Беларусь. 2006. URL : http://un.mfa.gov.by/docs/plenary_03.11.2006.pdf (дата обращения: 21.04.2020).

${ }^{23}$ CM. 19.
} 
представления доклада Генерального секретаря о работе Организации в рамках соответствующего пункта повестки дня, в то время как его выступление во время общих прений должно строго коррелировать с определяемой Ассамблеей проблематикой ${ }^{24}$.

Беларусь отмечает необходимость расширения практики проведения тематических дебатов ГА по ключевым проблемам современности. При этом подчеркивается, что тематические дебаты не должны проходить бесследно, а, напротив, очерчивать круг конкретных ориентиров и приоритетов для ООН в урегулировании обсуждаемой проблемы ${ }^{25}$. В качестве практически имплементируемой инициативы Беларусь приветствует проведение ежегодных тематических прений по вопросу о средствах разрешения споров и широкое привлечение экспертного звена к их работе 26 .

Подобное мероприятие уже реализуется на площадках Специального комитета по Уставу ООН и усилению роли Организации, а регулярный характер практики его проведения в ГА сможет облегчить приход к консенсусу по вопросам корректировки Устава ${ }^{27}$. При этом подчеркивается, что мероприятия такого характера, как и все без исключения заседания высокого уровня в период работы Генеральной Ассамблеи, должны обладать сбалансированным графиком и планироваться, обеспечивая полноценное участие делегаций. В этой связи в 2018 году Республика инициировала необходимость строгой регламентации процедуры организации и проведения такого рода мероприятий в соответствии с требованиями ГА путем принятия резолюции о модальностях и формате проведения заседаний высокого

\footnotetext{
${ }^{24}$ Выступление Постоянного представителя Республики Беларусь при ООН Валентина Рыбакова, п.110 «Доклад Генерального секретаря ООН о работе Организации», 72-ая сессия Генеральной Ассамблеи ООН // Министерство иностранных дел Республики Беларусь. 2017. URL : http://mfa.gov.by/upload/Rybakov_report\%20of\%20the\%20SG_2017.pdf (дата обращения: 22.04.2020).

${ }^{25}$ Strengthened and reformed UN. In: Ministry of Foreign Affairs of the Republic of Belarus. URL : http://mfa.gov.by/en/organizations/un/ (accessed 2020 April 26).

${ }^{26}$ Краткий отчет о 12-ом заседании Второго комитета 72-ой сессии Генеральной Ассамблеи $\mathrm{OOH,} \mathrm{выступление} \mathrm{г-жи} \mathrm{Багдасаровой} \mathrm{//} \mathrm{Цифровая} \mathrm{библиотека} \mathrm{Организации} \mathrm{Объединенных}$ Наций. 2017. URL : https://digitallibrary.un.org/record/1474551?ln=ru (дата обращения: 27.04.2020).

${ }^{27}$ Краткий отчет о 18-омзаседании шестого комитета 74-ой сессии Генеральной Ассамблеи ООН, выступление г-на Варанкова // Цифровая библиотека Организации Объединенных Наций. 2019. URL : https://digitallibrary.un.org/record/3856556? ln=ru (дата обращения: 18.08.2020).
} 
уровня $^{28}$. К сожалению, данная инициатива остается не реализованной до сих пор.

В качестве важного условия работы Генеральной Ассамблеи дипломатия Республики рассматривает возможность правомерного вмешательства ГА в работу Совета Безопасности в случаях, когда последний оказывается неспособным принять решение в период кризи$\mathrm{ca}^{29}$. В подобной ситуации, по мнению белорусской стороны, именно Генассамблея должна взять на себя решающую роль при условии строгой регламентации последней.

Беларусь желает видеть последовательное развитие сотрудничества и установление более тесных контактов Генеральной Ассамблеи и гражданского общества, подчеркивая при этом необходимость сохранения значения ООН как форума межправительственного общения. Белорусская сторона также поощряет укрепление парламентского измерения деятельности ООН путем расширения участия парламентариев в работе данной структуры ${ }^{30}$. Кроме развития сотрудничества в парламентском измерении, Беларусь настаивает на необходимости создания широкого экспертного диалога с участием представителей ведущих аналитических центров и экспертов правительственных структур. По утверждению А. Дапкюнаса, «Беларусь заинтересована в таком диалоге и намеревается всеми доступными средствами ему содействовать и его поддерживать» ${ }^{31}$.

Белорусская дипломатия считает необходимым продолжение работы в направлении укрепления роли Генеральной Ассамблеи как главного представительного и совещательного органа ООН в процессе реформирования ${ }^{32}$. В связи с этим Беларусь поддерживает стремление государств к усилению позиций Генассамблеи при избрании Генерального секретаря Организации ${ }^{33,34}$.

\footnotetext{
${ }^{28}$ CM. 15.

${ }^{29}$ CM. 25.

${ }^{30}$ Cм. 13.

31 О встрече заместителя Министра иностранных дел Беларуси А. Дапкюнаса с заместителем Генерального секретаря ООН по политическим вопросам // Министерство иностранных дел Республики Беларусь. 2018. URL : http://mfa.gov.by/press/news_mfa/fde7ef59fac90ffe.html (дата обращения: 22.04.2020).

${ }^{32}$ Cм. 16.

${ }^{33}$ См. 17.

${ }^{34}$ Выступление Министра иностранных дел Республики Беларусь С. Н. Мартынова на общей дискуссии // 66-я сессия Генеральной Ассамблеи. 2011. URL : https://www.un.org/ ru/ga/66/docs/belarus.pdf (дата обращения: 19.04.2020).
} 
В рамках данной проблемы Республика настаивает на обязательности соблюдения заложенного в Уставе принципа тайного голосования в качестве «не столько инструмента выбора, сколько средства сдерживания от внесения на рассмотрение Ассамблеи заведомо спорных предложений, которые не учитывают преобладающие в среде государств-членов настроения» ${ }^{35}$.

При подготовке к избранию Генерального секретаря официальный Минск исходит из необходимости повышения эффективности встреч, проводимых Генеральной Ассамблеей с кандидатами. В этой связи белорусская дипломатия выступила с несколькими конкретными предложениями. Во-первых, в рамках таких встреч необходимо отдавать предпочтение вопросам, инициируемым группами государств. Во-вторых, целесообразно предоставление возможности ответа кандидатов на один и тот же вопрос ${ }^{36}$.

Беларусь выступает за развитие практики проведения ознакомительных встреч по инициативе региональных групп, межгосударственных и неформальных объединений. При этом делается особый акцент на необходимость как можно большего вовлечения в такие мероприятия представителей Совета Безопасности как с целью ознакомления с кандидатами, так и для понимания настроений в Генеральной Ассамблее ${ }^{37}$. В этой связи подчеркивается важность усиления роли Председателя ГА, его заместителей и Канцелярии посредством наделения их большими возможностями по оптимизации выборного процесса и вовлечения, таким образом, в реформирование Ассамблеи. В этом контексте белорусская сторона выступает за выделение большей технической и финансовой помощи Председателю, в частности, во время официальных визитов, а также подчеркивает важность обеспечения лучшей «институциональной памяти» о его деятельности $^{38}$, что стало бы одним из звеньев механизма фиксирования Секретариатом ООН наиболее конструктивных точек зрения по вопросу активизации Генассамблеи, инициированного Беларусью

\footnotetext{
35 Выступление Постоянного представителя Республики Беларусь при ООН А. Дапкюнаса на заседании рабочей группы по активизации работы Генеральной Ассамблеи ООН // Министерство иностранных дел Республики Беларусь. 2016. URL http://mfa.gov.by/press/statements/eaa8b77a06ba9d89.html (дата обращения: 19.04.2020).

36 Там же.

37 Там же.

${ }^{38}$ CM. 25.
} 
еще в 2008 году ${ }^{39}$. При этом намерения по усилению роли ГА и ее Председателя в избрании Генсека не должны идти в разрез с заложенными в Устав ООН полномочиями Совета Безопасности ${ }^{40}$.

Беларусь поощряет оптимизацию выборов в другие центральные структуры ООН (к примеру, в Совет по правам человека, Экономический и Социальный Совет) с целью экономии времени, а также повышения эффективности и прозрачности системы подсчета голосов ${ }^{41}$. В данном контексте Республика Беларусь также делает акцент на достижении реального гендерного баланса как в рамках Генассамблеи, так и в других структурах и надеется, что будущая реформа сможет сыграть решающую роль в данном вопросе ${ }^{42}$.

Обсуждение полученных результатов. В историографии отсутствуют исследования о подходах Республики Беларусь к реформированию ГА ООН. С целью восполнить этот пробел и на основе документального материала, впервые введенного в научный оборот, выявлены ключевые инициативы и предложения белорусской стороны в векторе реформирования Генассамблеи, что позволило оценить позицию белорусской дипломатии по данному вопросу как центристскую. В перспективе, проведение сравнительного анализа позиции Беларуси и других государств будет способствовать выявлению потенциала двустороннего и многостороннего сотрудничества, позволит наладить действительно плодотворный диалог по вопросам реформирования Организации Объединенных Наций.

Выводы. Беларусь выступает за активизацию деятельности Генеральной Ассамблеи, в частности, посредством сокращения повестки дня и логичного рассмотрения ее пунктов с возможностью переноса процесса на двух- или трехлетнюю основу. Дипломатия республики призывает к устранению межинституционального дублирования

\footnotetext{
39 Официальный отчет 56-ого пленарного заседания 63-ей сессии Генеральной Ассамблеи ООН, выступление г-на Ярошевича // Цифровая библиотека Организации Объединенных Наций. 2008. URL : https://digitallibrary.un.org/record/641963?ln=ru (дата обращения: 26.04.2020).

${ }^{40}$ CM. 34.

${ }^{41}$ См. 25.

42 Выступление заместители министра иностранных дел Республики Беларусь С. Ф. Алейника в общеполитической дискуссии на 65-ой сессии Генеральной Ассамблеи $\mathrm{OOH} / /$ 65-ая сессия Генеральной Ассамблеи OОН. 2010. URL : https://www.un.org/ru/ga/65/meetings/pdf/belarus65.pdf (дата обращения: 29.03.2020).
} 
как в самой повестке, так и в резолюциях, принимаемых в соответствии с ней. Особое значение для белорусской стороны имеет расширение взаимодействия ГА с негосударственными объединениями, в частности, путем проведения открытых мероприятий; в рамках взаимодействия по линии СБ - ГА инициируется возможность правомерного вмешательства последней в случае неэффективности Совбеза. Минск подчеркивает необходимость активизации работы в направлении формализации взаимоотношений ГА и СБ, а также отдельных вопросов финансирования деятельности Организации. Белорусская сторона придает особую важность поддержанию международного диалога в качестве приоритетного формата кооперации как в рамках Генеральной Ассамблеи ООН, так и в других институтах Организации. При проведении выборов Генсека дипломатия республики считает задачей первостепенной важности строгое соблюдение процедуры, зафиксированной в Уставе, призывая, вместе с тем, к установлению действенного формата взаимодействия Генассамблеи, Совбеза и кандидатов на этот пост в целях наибольшей результативности выборного процесса. Реализация совокупности таких мер позволит актуализировать работу главного совещательного, директивного и представительного органа ООН.

Подводя итог, можно сделать вывод, что в отношении институциональной реформы Генеральной Ассамблеи Беларусь занимает «центристскую» позицию: предложения и инициативы Минска направлены главным образом на адаптацию и актуализацию работы этой структуры, не меняя ее основной роли и функций в системе ООН. Беларусь не стремится к реформам только ради реформ. Суть подходов Республики к модернизации Организации и входящих в нее структур метко передает фраза видного белорусского дипломата Виктора Гайсёнка: «Реформа осуществляется для того, чтобы каждый житель планеты почувствовал на себе защиту международного сообщества, поверив в свое лучшее будущее» ${ }^{43}$. В этой связи как никогда важно осознавать, что ООН и ее структурные подразделения - это не творения политических элит или государств; это творения, прежде

\footnotetext{
43 Выступление Заместителя Министра иностранных дел Республики Беларусь Виктора Гайсёнка на 61-й сессии Генеральной Ассамблеи ООН // Министерство иностранных дел Республики Беларусь. 2006. URL : http://mfa.gov.by/press/statements/c8a2c9da4862c336.html (дата обращения: 19.04.2020).
} 
всего, людей. «Все будет хорошо - знаете, когда? Когда люди, просто люди, перестают думать об Организации Объединенных Наций как о странной абстракции Пикассо и увидят ее как рисунок, который они сами нарисовали» (Даг Хаммаршельд, Генеральный секретарь ООН в 1953-1961 гг., лауреат Нобелевской премии мира).

\section{Библиографические ссылки}

1. Заемский В. Ф. Реформы ООН и миротворчество : дис. ... доктора полит. наук : 23.00.04. Москва. 2009. 352 л.

2. Юрченко М. М. Политика США в отношении реформирования ООН: 2001-2008 гг. : дис. ... кандидата истор. наук : 07.00.03. Тюмень. 2010. 227 л.

3. Голованов $E$. В. Проблема соотношения универсальной и региональных систем безопасности и реформа Совета Безопасности ООН : дис. ... кандидата полит. наук : 23.00.04. СанктПетербург. 2013. 228 л.

4. Паламаренко Р. Ю. ООН в XXI веке: проблемы реформирования : дис. ... кандидата полит. наук : 23.00.04. Москва. 2018. 170 л.

5. Сычев А. Н. Республика Беларусь и ООН //Дипломатический ежегодник-2005. Сборник статей ; под ред. Ю. Е. Фокина и др. Москва : Научная книга. 2006. С. 244-268.

6. Тихомиров А. В. Внешняя политика Республики Беларусь (1991-2015 гг.). Минск : БГУ. 2017. $208 \mathrm{c}$.

7. Тихомиров А. В. Взаимодействие Республики Беларусь и ООН (1991-2015 гг.) // Актуальные проблемы международных отношений и глобального развития редкол.; А. М. Байчоров (гл. ред.) [и др.]. 2015. Вып. 3. С. 261-276.

8. Внешняя политика Республики Беларусь в 2000-е годы / Ю. И. Малевич [и др.] ; под ред. А. В. Шарапо. Минск : БГУ. 2010. 84 с.

Дата поступления статьи: 20.11.2020.

Авторы: Лузан Даниил Вячеславович - студент факультета международных отношений Белорусского государственного университета, участник конкурсов и проектов по проблематике OOH; e-mail: fmo.luzanDV@bsu.by;

Свилас Светлана Францевна - доктор исторических наук, профессор кафедры международных отношений Белорусского государственного университета; e-mail: svilas@tut.by. 


\title{
THE APPROACHES OF THE REPUBLIC OF BELARUS TO THE INSTITUTIONAL REFORM OF THE UNITED NATIONS GENERAL ASSEMBLY IN 2005-2020 LUZAN D.V., SVILAS S.F. \\ Belarusian State University, Minsk, Republic of Belarus
}

\begin{abstract}
For more than 20 years, the world community has been actively seeking a solution to the problem of reforming the United Nations, but no consensus has been reached. In this regard, a detailed analysis of the positions of states is a significant step towards reaching agreement, allowing us to find common ground in reform projects.

Based on the analysis of the speeches of Belarusian diplomats from the UN rostrum and through an interdisciplinary methodology, the article defines the goals, principles, directions of participation of Belarusian diplomacy in the UN modernization process, contains a characteristic and a comprehensive assessment of the approaches of the Republic of Belarus to the institutional reform of the General Assembly. Three peaks of the republic's foreign policy activity in this area are highlighted, their content is revealed. Special attention is paid to such areas as the effectiveness of discussions, legal support for modernization, the system of financing, the UNGA agenda. The importance of expanding the practice of conducting thematic debates on the key issues, increasing the efficiency of interaction between the General Assembly and the Security Council, and developing cooperation with civil society was emphasized.

Belarusian diplomacy proceeds from the need to strengthen the role of the UNGA as the main representative and deliberative body of the UN, to strengthen the position of the Assembly, its Chairman and the Chancellery in the election of the Secretary General, but without prejudice to the powers of the Security Council. The conclusion is substantiated that Belarus takes a "centrist" position regarding the institutional reform of the General Assembly. The proposals of the Belarusian diplomacy are mainly aimed at adjusting the work of this body without changing its place and role in the system of the Organization.

The study aims to fill the gap in the scientific and journalistic literature in the study of the problems of reforming the General Assembly from the standpoint of the Republic of Belarus.
\end{abstract}


Key words: foreign policy and diplomacy of the Republic of Belarus; globalization; international cooperation; multilateral diplomacy; UN reform; UN General Assembly; anthropology of international relations.

For citation: Luzan D., Svilas S. (2020) The Approaches of the Republic of Belarus to the institutional reform of the United Nations General Assembly in 2005-2020. In: Actual problems of international relations and global development : collection of scientific papers. Minsk, Vol. 8, p. 58-74. https://doi.org/10.33581/2311-9470-2020-858-74

\section{References}

1. Zaemskiy, V. (2009). Reformy OON i mirotvorchestvo [The UN reform and peacekeeping] : the Dissertation of the Doctor of Sciences in Politics. Moscow, 352 p. (In Russ.)

2. Yurchenko, M. (2010). Politika SShA v otnoshenii reformirovanija OON: 2001-2008 gg. [US Policy on UN Reform: 2001-2008] : the Dissertation of PhD in History. Tyumen, 227 p. (In Russ.)

3. Golovanov, E. (2013). Problema sootnoshenija universal'noj i regional'nyh sistem bezopasnosti i reforma Soveta Bezopasnosti OON [The problem of the relationship between the universal and regional security systems and the reform of the UN Security Council] : the Dissertation of PhD in Politics. St. Petersburg, 228 p. (In Russ.)

4. Palamarenko, R. (2018). OON v XXI veke: problemy reformirovanija [The UN in the XXI century: problems of reform]: the Dissertation of PhD in Politics. Moscow, 170 p. (In Russ.)

5. Sychov, A. (2006). Respublika Belarus' i OON [The Republic of Belarus and the UN]. In: Diplomatic Yearbook-2005. Collection of papers. Moscow, p. 244-268. (In Russ.)

6. Tihomirov, A. (2017). Vneshnjaja politika Respubliki Belarus' (1991-2015 gg.) [Foreign policy of the Republic of Belarus (1991-2015)]. Minsk, 208 p. (In Russ.)

7. Tihomirov, A. (2015). Vzaimodejstvie Respubliki Belarus' i OON (1991-2015 gg.) [Interaction between the Republic of Belarus and the UN] In: Actual problems of international relations and global development : collection of scientific papers. Minsk, Vol. 3, p. 261-276. (In Russ.)

Received: 20.11 .2020 .

About authors: Daniil V. Luzan - student of the Faculty of International Relations of the Belarusian State University, participant of competitions and projects on UN issues; e-mail: fmo.luzanDV@bsu.by;

Svetlana F. Svilas - Doctor of Sciences in History, Professor of the Department of International Relations of the Belarusian State University; e-mail: svilas@tut.by. 